\title{
Los poetas ciegos y la ceguera en la poesía árabe: algunos casos destacados
}

\section{Blinds poets and Blindness in Arab poetry: outstanding cases}

\author{
Josefina VEGLISON ELIAS DE MOLINS \\ Universidad de Valencia \\ josefina.veglison@uv.es
}

Recibido: octubre 2012

Aceptado: abril 2013

\section{RESUMEN}

El artículo se ocupa de los versos de algunos poetas árabes ciegos que se han hecho famosos en la literatura árabe clásica y que nos hablan de la ceguera como es el caso de al-A 'šàà, Baššār ibn Burd y Abū-l-'Alā' al-Ma arrī entre otros. Se analiza la actitud de cada uno frente a su discapacidad y la influencia que tuvo su invidencia en su producción poética. El estudio, en el que se traducen los versos desde su original árabe, trata también de los versos que los ciegos inspiraron a algunos poetas videntes de Granada y a otros de la poesía árabe contemporánea.

Palabras clave: poesía árabe clásica, ceguera, poetas ciegos, al-A ‘šà, Baššār ibn Burd, Abū-l- 'Alā’ alMa'arrī.

\begin{abstract}
This paper deals with the verses of some relevant and famous blind Arab classical poets that talked about their blindness like the cases of al-A ššà, Baššār ibn Burd and Abū-l- ${ }^{\mathrm{C}} \mathrm{Alā}{ }^{\prime}$ al-Ma arrī among others. The study shows how each one of them faced his disability and the influence that their blindness had on their poetic production. This paper contains also the translation from the Arabic and tha analysis of the verses inspired by blindness to some seeing poets of Granada and the moderm Arabic poetry.

Keywords: Arab classical poetry, blindness, blind Arab poets, al-A“šà, Baššār ibn Burd, Abū-1-'Alā’ al-Ma'arrī.

SUMARIO: 1. Introducción, 2. Al-A`šà (m. 629) y Baššār ibn Burd (m. 784), 3. Abū-1- Alā’ alMa ${ }^{\circ} \operatorname{arrī~(m.~1057),~4.~Abū-l-Ḥasan~al-Ḥușrī~al-Qayrawānī~(m.~1095),~5.~Al-A~mà~al-Tuṭ̂ilī~(m.~1126),~}$ 6. La ceguera como motivo literario en los autores videntes, 7. A modo de conclusión.
\end{abstract}




\section{INTRODUCCIÓN}

En numerosas culturas ha habido importantes literatos ciegos' ${ }^{1}$; sin embargo, la acusada prevalencia de la ceguera en toda la geografía árabe ${ }^{2}$ hace que el número de poetas invidentes en esta cultura sea, en proporción, muy elevado, hasta el extremo de que al-Ṣafadī (s. XIV) elaboró un diccionario biográfico para recoger la memoria literaria de ciegos ilustres, el Nakt al-himyān fì-nukat al-'umyān. Grandes figuras de nuestros días lo son también; es el caso de Ṭāhā Ḥusayn (1889-1973), padre de la Nahda egipcia y forjador de la novela, o el poeta yemení 'Abd Allāh al-Baradūnī ${ }^{3}$ (1929-1999), quienes contrajeron la ceguera en la infancia como secuela de una viruela mal curada.

Por todo ello no debe extrañarnos que la lengua árabe posea distintos términos para calificar al invidente: $a^{\prime} m a ̀$, designa al ciego total junto con kafíf y makfüf, más coloquiales; akmah, designa al ciego de nacimiento; $a \check{s} \grave{s}^{4}$, designa a quien tiene muy disminuida su capacidad visual; darìr, es una acepción más literaria para referirse al invidente de forma respetuosa. A menudo se da la kunya "Abū Bașīr", utilizada como antónimo, a autores medievales que fueron ciegos.

Cuando leemos los versos de los poetas árabes ciegos que más destacaron en el período clásico llaman la atención sus constantes referencias a fenómenos o descripciones en los que la vista desempeña un papel fundamental como si se tratara del fruto de una observación real cuando, en realidad, se trata de una figuración mental (en el caso de los ciegos de nacimiento) o de un recuerdo (en el caso de aquellos que padecieron ceguera sobrevenida) pero, en todo caso, la pérdida de la visión les incita a imaginarla o rememorarla con una agudeza que no encontramos en los poetas videntes; para explicar este fenómeno hay que tener en cuenta el riquísimo repertorio de imágenes descriptivas del legado poético clásico y valorarlas como fondo de recursos inagotable del que estos poetas, sin duda, echan

\footnotetext{
${ }^{1}$ Entre los más destacados el mítico Homero en la Grecia clásica; John Milton en la anglosajona, quien perdió la vista en 1652, por lo que escribió su obra cumbre, The Paradise lost, en 1667, siendo ya ciego, y Jorge Luis Borges (1899-1986) en la hispánica, quien perdió la vista de forma progresiva a partir de 1955.

${ }^{2}$ El primer estudio sobre la gran prevalencia de la ceguera en Oriente Medio lo debemos al Dr. René Nicolas Desgenettes (m. 1837), jefe del equipo médico de Napoleón durante la ocupación de Egipto, en un informe que presentó ante el Instituto francés de El Cairo en 1798, momento en el que un tercio de la población de la ciudad sufría discapacidad visual en distinto grado.

${ }^{3}$ Autor de 12 dīwānes de poesía árabe clásica y distintas publicaciones sobre poesía y cultura popular yemeníes.

${ }^{4}$ IBN MANẒŪR, “Sū' al-basar bi-l-layl wa-l-nahār" Lisān al- 'arab, ed. Yūsuf Jayyāt. Beirut, sd. II, p. 787. Según esta fuente, al menos tres poetas preislámicos son conocidos como al- A ‘̌s̀à: A“šà banī Qays Abū Basīir, A šà Bāhila Abū Qụ̂ăfa, A šà ban̄̄ Nahšal al-Aswad, y cuatro en la época islámica:

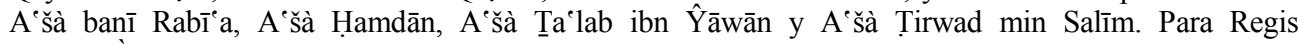
BLACHÈRE, dado el elevado número de poetas que en la Arabia preislámica llevaron este sobrenombre (17), no es descartable que éste designase a algún grupo tribal o bien la calidad excelsa del poeta. Véase: "Un problème d'histoire littéraire: A šà Maymūn et son oeuvre" Arabica 10 (1963), 24-55.
} 
mano, pues en la cultura literaria árabe el poeta para dominar su oficio debe ejercitarse en la lectura de los versos de los antiguos que le precedieron.

Todos ellos nos dejaron constancia de su particular visión de la ceguera -sobre todo Baššăr Ibn Burd, el único ciego de nacimiento- y de cómo ésta afectó a sus vidas, en especial a su relación con los demás, y a su obra. Las pinceladas autobiográficas, a las que tan reacios son los clásicos árabes, son aquí frecuentes y se presentan teñidas de un pesimismo que, en ocasiones, conduce al sarcasmo y la ironía y en otras a la introspección reflexiva o a una actitud resignada, en todo caso siempre bajo una impronta común de tristeza y amargura.

\section{AL-A'ŠÀ (M. 629) Y BAŠŠĀR IBN BURD (M. 784)}

Comenzaremos con la lectura de un célebre autor de mu'allaqa ${ }^{5}$, tenido con frecuencia por ciego o, al menos, con una vista muy mermada, Abū Bașīr al-A ššà Maymūn ibn Qays; y ello con todas las reservas con que debe encarase su producción poética ${ }^{6}$, llena de indicios de manipulación: desde su pretendida confesión cristiana, pasando por el panegírico que, supuestamente, habría dedicado a Mahoma, y terminando por su poesía báquica, tan al estilo de aquella del primer período 'abbāsí. Resulta curioso, por lo excepcional, que no aludiera en su obra a la ceguera sino de forma superficial, como hace en su mu allaqa:

¿Qué ignorante Umm Hַulayd! ¿A quien se une?

Acaso por verme cegato y víctima

de mortal aprehensión y fatal fortuna,

dijo Hurayrah cuando fui a visitarla:

"Ay de ti, ay de mí, por tu causa, hombre?"

Con este verso, recogido en numerosas antologías, describe el fondo de una crátera llena de vino:

Cuánto vino escarlata bebí en una vasija

en cuyo fondo podía verse, como en el ojo, una mota. ${ }^{8}$

Sorprende la nitidez de esta comparación en ojos de un supuesto invidente. Abū-1-Faraŷ al-Iṣfahān̄în declaró que la poesía de Baššār ibn Burd se asemeja a la

\footnotetext{
${ }^{5}$ Traducción en F. CORRIENTE y J. P. MONFERRER, Las diez mu'allaqāt. Madrid 2005, 181-186.

${ }^{6}$ Como señaló y razonó ḌAYF, Šawqī en Ta'rīj al-adab al- 'arabī, al- 'asr al-ȳāhilī. El cairo 1960, 333-365, especialmente en pp. 335 y 349, y BLACHÈRE, Regis, Arabica 10 (1963), 24-55.

${ }^{7}$ CORRIENTE, Las diez mu'allaqāt, p. 183.

${ }^{8}$ AL-A'Š̀̀, Mutaqārib, bi-hā. Dīwān al-A '̌sà. Beirut 1966, p. 24, v. 19. IBN QUTAYBA, Kitāb alši 'r wa-l-šu 'arā', ed. M. Qumayhạ. Beirut 19852, 26; AL-ŶĀḤIZ, Kitāb al-bujalā', ed. F. 'Ațīi. Beirut 1969, 92 y AL-'ASKARĪ, Kitāo al-sinā 'atayn, al kitāba wa-l-ši 'r, ed. M. Qumayḥa. Beirut 19892, 504.

${ }^{9}$ Véase nota 4.

${ }^{10}$ AL-IṢFAHĀNĪ, Abū-l-Faraŷ, Kitāb al-agānī, ed. ‘Abd al-Sattār Aḥmad Farrāŷ. Beirut 1981, III, p. 141.
} 
de al-A ‘̌sà, mientras que al-Ŷăhị comentó ${ }^{11}$ lo curioso que resulta que dos poetas ciegos describan con tal calidad óptica ciertos aspectos cromáticos. Saca a colación un verso de al-A šàà, para cuya comprensión nos explica que, según el canon de belleza femenino, la mujer atractiva tiene el blanco de los ojos brillante o tirando a rojo de día, y amarillento de noche:

Blancos (los ojos) de mañana y atezados de noche como las partes expuestas del cuerpo. ${ }^{12}$

Y a continuación incluye este otro de Baššār, para terminar afirmando que ninguno de los dos versos podría ser mejorado por un vidente:

Ponte vestimenta ornada y coloreada, la más excelsa,

y, cuando yo entre, vélate de rojo el rostro, pues la belleza es escarlata. ${ }^{13}$

La imagen que vemos a continuación de la mano de Baššār parece también insólita en quien jamás vio el vuelo de un pájaro, ni el escanciar de un botijo ni el resplandor de un rubí:

Nuestro cántaro, con la gota en su caño, parece un pájaro que llevase un rubí en el pico. ${ }^{14}$

O la belleza de un lunar en la mejilla de una esclava negra. La negritud de algunas esclavas era para Baššăr motivo de inspiración recurrente. Cuando podían atraerle por cualquier otro sentido él poetiza sobre su color, que desconoce, y satiriza sobre la ausencia de éste. Estamos ante una filigrana propia de una retórica innovadora: la contra antítesis y el reverso del claroscuro, figuras a las que tan aficionados fueron los poetas modernistas:

El lunar en esa mejilla sin tacha le hace ganar en gracia y belleza

pero ¿cómo gusta tanto a quien lo mira si no se ve su color? ${ }^{15}$

De pie o sentada te pareces al almizcle y el almizcle se parece a ti.

Sin duda el mismo es vuestro color, de la misma pasta estáis hechos ambos. ${ }^{16}$

Si a menudo se ha calificado la autobiografía al-Ayyām (Los días) de Țāhā Husayn como prosa de ciego por la ausencia del sentido de la vista al transmitirnos sus sensaciones y la importancia que en ella cobra el sentido auditivo ${ }^{17}$, no podemos decir lo mismo de la poesía de Baššār, que es poesía de vidente, por el importante

${ }^{11}$ AL-Ŷ̀̄ḦIZ, Kitāb al-bayān wa-l-tabyīn, ed. Muwaffaq Šihāb al-Dīn. Beirut 1998, I, p. 156.

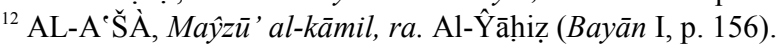

${ }^{13}$ Maŷzū' al-kāmil, ri., p. 156 y en Dīwān Baššăr Ibn Burd, ed. Șalāḥ al-Dīn al-Hawārī. Beirut 1998, IV, p. 57.

${ }^{14}$ Basìt, ri. Dīwān Baššăr IV, p. 80.

${ }^{15}$ Wäfir, lā, Ibid IV, p. 137.

${ }^{16}$ Sarī', da-hu. Ibid IV, p. 42. IBN 'ABD RABBIHI, al-Iqd al-farīd, ed. M. Qumayha. Beirut 19873, III, p. 148. Véanse otros versos a una esclava negra en AL-IȘFAHĀNĪ, Agānī. Op. Cit. III, p. 188.

${ }^{17}$ Véase CACHIA, P., Tăhā Husayn: his place in the Egyptian literary renaissance [1956]. Georgias Press 2005, pp. 67 y ss. MALTI-DOUGLAS, Fedwa, Blindness and autobiography, AlAyyam of Taha Husayn. Princeton University Press 1988. 
papel que la vista desempeña en sus versos siendo el sentido que, paradójicamente, juega un papel más importante ${ }^{18}$, lo que queda de manifiesto en la frecuencia con que usa los verbos "ver" y "mirar" en primera persona, pues es a través del amado como logra mirar y ver:

Para poder tener un encuentro contigo me mostré contenido, sin éxito.

No envidio de ti la belleza sino el velo que la arropa.

Oh, luz de mis ojos, a través de la que yo miraba, cuando desapareciste dejé de dormir, oír y ver quedando en lo más profundo de mis entrañas la pasión de tu amor.

Nada pierde ni gana el ciego bajo las alas de la noche.

Temo la muerte con deseo y resignación, mas sin paciencia.

Ni vivo ni muerto, sino siempre a la espera. ${ }^{19}$

Dice al-Ișfahānī que era el ciego más feo y horripilante de aspecto, pero también asegura que describía mejor que los videntes y que cuando se le preguntó por ello respondió: "la ausencia de visión fortalece la inteligencia del corazón pues le permite no estar ocupado mirando las cosas, acrecienta sus sentidos y agudiza su talento" ${ }^{20}$, y agrega: "Baššār no vio nunca nada del mundo pero podía describir lo que no eran capaces de ver aquellos que tenían los ojos bien abiertos" ${ }^{21}$. Esta habilidad inesperada sorprendía a quienes le rodeaban, como le ocurrió a una esclava de la que se quedó prendado:

Perla marina escondida que el comerciante ha selecciontado entre tantas otras.

Se asombra Fatima de mi descripción, pues ¿puede acaso un ciego brillar en tales artes? ${ }^{22}$

Aunque, en ocasiones, no era sorpresa lo que suscitaba entre las mujeres sino rechazo, como el de aquella que le reprocha que siendo feo y ciego se atreva a cortejarla ${ }^{23}$. Lo mismo le ocurría con los hombres; Hammād Aŷrad ${ }^{24}$ le espetó: "Eres más feo que un mono, si es que hay monos ciegos" ${ }^{25}$. Pero él se armaba de sarcasmo frente a tales situaciones:

Umāma, me han descrito tu belleza pero yo no te veo, así que tócame. ${ }^{26}$

Mis ojos ayunan de las mujeres hasta el día en que rompa el ayuno con las huríes. ${ }^{27}$

\footnotetext{
${ }^{18}$ Véase GHEDIRA, A., "La fréquence du mot 'ayn/oeil dans les poèmes de Baššār l'aveugle" Arabica 28 (1981), 1-38.

${ }^{19}$ Hazầ, rā'. Dīwān Bǎ̌šār III, p. 192-193.

${ }^{20}$ Kitāb al-agānī III, p. 143.

${ }^{21}$ Kitāb al-agānī III, p. 142.

${ }^{22}$ Ramal, ri. Dīwān, IV, p. 57.

${ }^{23}$ Kitāb al-agānī III, p. 192.

${ }^{24}$ Șāhib al-šurța (jefe de policía) de la ciudad de Kufa quien acusó a Baššār de herejía (zandaqa).

${ }^{25}$ AL-'ASKARĪ, Kitāa al-sinā'atayn. Op. Cit, p. 404.

${ }^{26}$ Wāfir, nā. Dīwān IV, p. 186.

${ }^{27}$ Basìt, rì. Dìwān III, p. 290.
} 
Baššār introdujo en el gazal (género poético amoroso) los amores en masculino plural dedicados a los gilmān (muchachos), que impondría después Abū Nuwās (m. 814) y que tanto éxito y cultivadores cosecharon en al-Andalus. En los versos siguientes nos revela cual es el órgano responsable de sus enamoramientos:

Gentes, mi oído se ha enamorado pues el oído se enamora, a veces, antes que el ojo.

Me dicen: ¿deliras por alguien a quien no viste?

Respondo: el oído, como el ojo, se prenda antes que el corazón. ${ }^{28}$

Aunque el corazón es, para el poeta, instrumento de conocimiento pues "el corazón ve lo que no ve la mirada" ${ }^{29}$.

Ibn Jallikān señala que el primer verso fue retomado por Ibn al-Šaḥna al-Mawșūlī en una casida de loa a Saladino; lo que no nos dice es que aquello que, en principio, podría parecer un hallazgo de Baššăr o un simple toque de sinceridad -al ser éste ciego- es tan sólo un préstamo literario ya que Baššăr, a su vez, tomó el contenido del 'udrī Kutayyir 'Azza: "Si la oyeran hablar, como yo la oí caerían rendidos ante ella postrándose a sus pies" ${ }^{\prime{ }^{30}}$. El enamoramiento de oídas no es, pues, exclusivo de los invidentes.

No obstante, el motivo recurrente de los ojos como arma de amor se impone a la realidad de un ciego que no puede ver esos ni otros ojos. Ibn Jallikān ${ }^{31}$ cita este verso de Baššār como el "mejor verso amoroso de los modernos":

Por Dios, deseo con ardor tus ojos fascinantes

pero temo el campo de batalla de los enamorados.

Baššār era un incondicional del amor en todas sus formas y, pese a la modernidad de sus imágenes, a menudo asoma en sus versos el mundo antiguo, como en éstos, de reminiscencias 'udries, que desvelan su creencia en los poderes curativos y milagrosos del cuerpo de la amada para devolverle la vista que el dinero no le puede restituir:

Si tuviera un encuentro contigo a solas y sin testigos, curarías lo que la medicina no cura. ${ }^{32}$ Aunque poseyera todo el oro de mundo, éste no sería suficiente para devolverme la salud. ${ }^{33}$

Tú eres la única cuya visión me cura la vista, las otras son agua que no has de beber. ${ }^{34}$

La ceguera no era sentida por el poeta como una limitación, sino como un don, tal y como lo vio Borges tantos siglos después ${ }^{35}$, pues se enorgullecía de su calidad de ciego al considerar que esa discapacidad le hacía, en lo intelectual, superior a los demás:

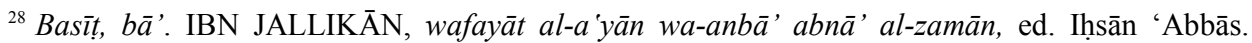
Beirut 1978, I, p. 272.

${ }^{29}$ Basìt, ru. Dīwān, III, p. 214.

${ }^{30}$ Basìt, dā'. En IBN 'ABD RABBIHI, al-'Iqd al-farìd. Op. Cit I, p. 338.

${ }^{31}$ Jafîf, qi, IBN JALLIKĀN, wafayāt, I, p. 272.

${ }^{32}$ Basìt, bu. Dīwān I, p. 184.

${ }^{33}$ Basìt, di. Dìwān III, p. 139.

${ }^{34}$ Basìt, ūbì. Dīwān I, p. 253.

${ }^{35}$ Así lo declara en su "Discurso sobre la ceguera" BORGES, Jorge Luis, Siete noches. Buenos Aires 1980, pp. 143-160. 
Al tratar de injuriarme mis enemigos se equivocan, no es un oprobio ser llamado ciego. Si observa la hombría y el temor de Dios, el ciego no daña a nadie.

Para mí la ceguera es don, provisión y protección, tres cosas de las que estoy necesitado. ${ }^{36}$

Cuando el niño nace ciego, con el tiempo lo verás mejor encaminado que al vidente. En el útero materno quedé ciego, mas la inteligencia es atributo de la ceguera pues vine al mundo con un asombroso pensamiento, refugio para la ciencia. Mientras las gentes andaban perdidas en pos de esto y aquello se desvaneció la luz de los ojos para encerrarse en un corazón y en una poesía con palabras cual flores de jardín entre las que reino ya que, cuanto más triste, mejor fluye la poesía. ${ }^{37}$

Dicen: la ceguera es horrible espectáculo. Sí, mas no veros la hace más llevadera. Dios ha querido que no haya ni una sola cosa en el país de cuya pérdida deban consolarse los ojos. ${ }^{38}$

La ceguera se cura preguntando constantemente, mientras alcanza su paroxismo si callas ante aquello que ignoras. Indaga, pues, acerca de todo aquello que te interesa. ${ }^{39}$

El sarcasmo acerca de su condición es el segundo ingrediente con que encara su discapacidad, lo que queda patente cuando nos relata cómo, en cierta ocasión, tuvo que guiar a un hombre hasta una casa pues con las explicaciones que le dio no fue suficiente:

Un ciego conduce a un vidente. No temáis que pierda su camino, le guía un ciego. ${ }^{40}$

O cuando con ironía plasma sus dificultades a la hora de realizar la oración en unos versos que pueden encerrar disculpas por no responder a saludos recibidos:

Cuando asisto a la oración provoco la risa de quienes me ven.

Me siento prosternándome cuando los demás se inclinan

y alzo la cabeza cuando todos se prosternan.

Si se inclinan a la vez, yo me prosterno y me siento antes que nadie.

Tampoco sé a quién saluda el imam cuando inclina la cabeza. ${ }^{41}$

Entre las numerosas noticias (ajbār) recogidas por al-Ișfahān̄̄ sobre el poeta destaca el tono socarrón con que hablaba de su invidencia. Un criado le presentó un recibo de 10 dirhams por la compra de un espejo y Baššār le gritó: "No hay en el mundo nada más sorprendente que un espejo para ciegos por 10 dirhams. Por Dios, nadie pagaría por él ese precio ni aunque pudiese verse en él reflejado tras apagarse el sol y quedarse el mundo en tinieblas"42. También bromeó a propósito de un sastre tuerto de nombre 'Amrū:

\footnotetext{
${ }^{36}$ Tawìl, ru. Dīwān IV, p. 69.

${ }^{37}$ Tawìl, lā. Dīwān IV, p. 135.

${ }^{38}$ Maŷzū ${ }^{`}$ al-basìt, ùnu. Dìwān IV, p. 188.

${ }^{39}$ Tawìl, li. Dīwān IV, p. 149.

${ }^{40}$ Basịt, dì-hi, Dīwān IV, p. 205.

${ }^{41}$ Munsariḥ, dū. Dīwān, IV, p. 48.

${ }^{42}$ Agānī III, p. 155.
} 
'Amrū me ha cosido una túnica, ojalá sus ojos fueran igual.

Acabo de componer unos versos que no se sabe si son sátira o loa. ${ }^{43}$

Esa dolencia, que aguzó su sarcasmo y amargura, fue quizás la que le llevó a compartir con al-Ma arrī una inusual sensibilidad para con los animales y los débiles que se ve acrecentada frente al dolor y miserias de los demás. Sabemos que dedicó un poema a su asno cuando éste murió y se le apareció en sueños ${ }^{44} \mathrm{y}$ que daba una cantidad anual a Abū-1-Šamaqmaq ${ }^{45}$ (m. 796), poeta miserable, considerado un paria pues vivía en la marginalidad y subsistencia más precarias.

\section{ABŪ-L-'ALĀ'AL-MA'ARRĪ (M. 1057)}

Este poeta cierra el periodo de esplendor de la poesía árabe clásica en Oriente, no sin antes haber abierto nuevos aires de reflexión sobre el universo y las religiones, así como sobre la necesidad de ser más respetuosos con las plantas y los animales. Acerca de la pérdida de la vista explicó: "Yo no conozco los colores, salvo el rojo, porque cuando padecí la viruela me vistieron un traje teñido de cártamo y sólo me acuerdo de este color" ${ }^{\prime 4}$. Quizás sea el ciego que más sufrió por su incapacidad añadiendo un tormento más al hecho de tener que vivir, pues no es un secreto para nadie que no amaba la vida, su vida, a la que compara con una candela:

Pálida como yo ahí sigue consumiéndose con el paso de los días, la estrechez y la opresión mostrando siempre una sonrisa resplandeciente y paciente pese a ser su sino la extinción. De poder hablar diría: creo que pensáis que lloro por temor a la extinción.

No os asombre su risa ni su sonrisa pues a veces los ojos lloran de tanto reír. ${ }^{47}$

Motivo que retomará más adelante Abū-1-Ṣalt de $\operatorname{Denia}^{48}$ (m. 1134).

De su ceguera, que definía como la primera de sus tres cárceles, ${ }^{49}$-siendo la segunda su casa, en la que se recluyó, y la tercera su vil cuerpo que atrapaba al espíritu- describe ese horizonte punteado de blanco que nosotros erróneamente creemos son las tinieblas del ciego:

Esta noche mía es como una novia negra con collares de perlas. ${ }^{50}$

${ }^{43}$ Maŷzū' al-ramal, $\bar{a}$ '. Dīwān, IV, p. 7.

${ }^{44} A g \bar{a} n \bar{\imath}$ III, p. 226.

${ }^{45}$ Agānī III, p. 188. Véase GUNEBRAUM, G. E., "Abū-l-Šamaqmaq" Encyclopédie de l'Islam I, $2^{\circ}$ ed. p. 154. Pueden leerse algunos de sus versos en VEGLISON, J., El Collar único de Ibn 'Abd Rabbihi. Madrid 2007, p. 104 y Dīwān Abī-l-Šamaqmaq, ed. Wādiḥ Muḥammad al-Ṣamad. Beirut 1995.

${ }^{46}$ AL-MA 'ARRĪ, Abū-l-'Alā', Al-luzūmiyyāt, ed. 'Umar Abū-l-Nașr. Beirut 1969, p. 6.

${ }^{47}$ Tawìl, ki. IBN JALLIKĀN V, p. 398- 399.

${ }^{48}$ Tawāl, 'a. Dīwān Abī-l-Salt al-Dānī, ed. Muḥammad al-Marzūqī. Túnez 1974, no 238, p. 83. Véase su traducción en LABARTA, BARCELÓ, VEGLISON. València àrab en prosa i vers. Valencia 2011, nº 248, p. 170.

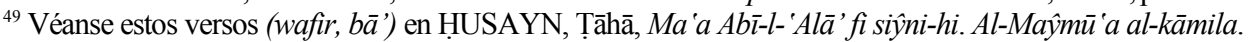
Beirut 1983 X, p. 329 y su traducción en VEGLISON, J., La poesía árabe clásica. Madrid 2002, P. 200.

${ }^{50}$ Wāfir, nūn. En ḤUSAYN, Tāhā, Taŷdīd dikr Abì-l-'Alā', Al-Maŷmū'a al-kāmila, Beirut 1983, X, p. 211. 
Aunque las referencias visuales no son habituales en su poesía, que sí se reconoce como poesía de ciego frente a la de Baššār, algunas resultan muy logradas:

A los ojos parecen pequeñas las estrellas y no son ellas quienes engañan, sino nuestra mirada. ${ }^{51}$

Especialmente interesante su alusión a la lectura por el tacto ${ }^{52}$ :

El astrónomo de las gentes es como un ciego que lee sus páginas al tacto. ${ }^{53}$

La visión que nos da de su minusvalía es unilateral, amarga; la ceguera es fuente de reflexión y motor al retiro, todo lo contrario de la polifacética visión de Baššār que reunía orgullo, sarcasmo y desprecio hacia los demás. Son las dos visiones contrapuestas de un modernista innovador y cambiante frente a un neoclásico conservador y pesimista. Es la humanidad entera la que está ciega pero en esa oscuridad el ciego resulta, de nuevo, el más clarividente:

Soy ciego, pero ¿cómo ser bien guiado si todas las gentes son ciegas?

El cayado es mejor guía para el ciego que el hombre libertino y desobediente. ${ }^{54}$

El más clarividente es ciego como yo. Venid, chocaremos en una noche tenebrosa. ${ }^{55}$

Fíate del ciego cuando cojas su diestra para guiarle $\mathrm{y}$ corta con tus sordas percepciones. ${ }^{56}$

A la ceguera de los ojos sigue la ceguera de la religión y la de la revelación.

Por eso, mi noche es la más extrema: son tres noches. ${ }^{57}$

Ma arrī aborda su ceguera desde una dimensión reflexiva, metafísica. Si su reclusión era triple (ceguera, enclaustramiento, cuerpo), triple es también la oscuridad en la que se debate pues, a la mera ceguera física, se añaden las otras dos, de carácter intelectual. La duda que le corroía acerca de la resurrección y la inmortalidad del alma, en las que coinciden las tres grandes religiones reveladas, le lleva también a plantearse la veracidad y credibilidad de esos distintos sistemas religiosos que se sucedieron modificando cada uno al anterior cuando no invalidándolo. La ceguera de los ojos es para el poeta anecdótica comparada con el hecho de que no podamos responder a las grandes cuestiones que preocupan al hombre: ¿Qué somos, de dónde venimos, adónde vamos y, sobre todo, el alma sobrevive al cuerpo y, de no ser así, para qué venimos a este mundo?

En su obra Con Abū-l- 'Alā' en su prisión, Țāhā Husayn se identifica con el gran pensador, comprende su apartamiento y reclusión y siente una enorme compasión por él:

${ }^{51}$ Basīit, ri. IBN JALLİKĀN, Op. Cit, V, p. 290.

${ }^{52}$ Véase sobre este aspecto ŶARRĀR, Șalāḥ, "Ṭarīqa al-qirā'a 'inda al-makfūfīn bașriyyīn fì qașā'id min al-ši 'r al-andalusî̀" en Maŷalla maŷma' al-luga al- 'arabiyya al-urdun, 61 (2001), 77-105.

${ }^{53}$ Wãfir, sīn, en HUUSAYN, Țāhā, Ma'a Abì-l-'Alà fí-siŷni-hi, p. 387.

${ }^{54}$ Wãfir, yãn. AL-MA ARR $\overline{\bar{I}}$, Abū-1-'Alā', Al-luzümiyyāt, Op. Cit, p. 216-217.

${ }^{55}$ HUUSAYN, Ṭāhā, Con Abū-l-'Alā' en su prisión, trd. J.M. Carabaza. Madrid 1990, p. 43.

${ }^{56}$ Ṭawìl, mā. AL-MA'ARRĪ, Abū-1-'Alā', Al-luzümiyyāt, P204.

${ }^{57}$ Tawīl, yāli. Ibid, P192. 
"Le decía a Abū-l- Alā' que su pesimismo no tenía origen, en realidad, más que en la incapacidad de saborear la vida y en la dificultad de sentir la belleza, la alegría, el bienestar y el placer que puede haber en ella. El me respondía: en cambio tú estás satisfecho de lo que no conoces y te asombras de lo que no ves". Para el autor, el orgullo es el motivo de la desgracia del poeta, un orgullo que "le llevó a intentar lo que le resultaba imposible, a codiciar lo que no debía y a desear lo que no estaba a su alcance. Abū-l-'Alā' abusó de la fe y confianza en su razón y rechazó todo lo demás"s8

Sabemos que a Ma arrī le molestaba tener que dictar sus versos: "¿Es que, según parece, no voy a tener nunca un descanso de esta penosa tarea de dictar?" ${ }^{9} \mathrm{y}$, al igual que le sucedía a Baššār, no le gustaba que se aludiera a su ceguera, como prueba el incidente que por este motivo tuvo con Abū-l-Hasan al-Rabā ${ }^{\top} \overline{1}^{60}$, o el que sufrió con Ibn Hind al-Ḥumși cuando éste le espetó: "Abū-l-'Alā' ibn Sulaymān, Dios te ha hecho un favor al concederte la ceguera", a lo que replicó Ma'arrī: "Dicen que la ceguera es horrible de ver y respondo que peor es verte a ti" ${ }^{61}$. A éstos, cabe añadir el percance sufrido con un lector coránico de los mejores de Ma'arra quien, para herirle, le leyó esta aleya coránica: "Cualquiera que sea ciego en este mundo lo será en el otro y andará aún más extraviado" (XVII, 72). Ma'arrī le replicó con estos versos: "El tal Abū-l-Qāsim es prodigioso caso de saber y no saber. Es poeta y lector coránico pero ni compone poemas ni sabe leer el Corán" ${ }_{62}$

Sobre la visión que estos poetas árabes medievales tienen de su ceguera gravita sin duda el peso de la visión islámica; a la aleya citada podemos añadir ésta otra: "No son los ojos los que están ciegos sino los corazones en el pecho de los hombres" (XXII, 46) en la que se considera de mayor gravedad la ceguera moral e intelectual frente a la verdad que la física frente al mundo tangible que nos rodea.

\section{ABŪ-L-ḤASAN AL-ḤUȘRĪ AL-QAYRAWĀNĪ (M. 1095)}

Según Ibn Bassãm, el estilo de Ma arrī fue seguido e imitado por Abū-1-Hasan al-Ḥușrī, aunque sin alcanzarlo ${ }^{63}$, lo que manifiesta citando estos versos de Ibn alAḥnaf: "Es como el sol, que tiene sede en el cielo, y subyuga el corazón con su hermoso poderío, pero éste no puede ascender hasta él ni él bajar hasta ti” ${ }^{64}$. El comentario final es, si cabe, todavía más displicente: "Qué lejos está para un ciego el juntar la tierra con el cielo".

${ }^{58}$ HUUSAYN, Ṭāhā, Con Abū-l- 'Alā' en su prisión, pp. 19 y 43.

${ }^{59}$ HUUSAYN, Ṭāhā, Con Abū-l-'Alā' en su prisión, p. 109.

${ }^{60}$ Ảbū-l-Hasan al-Rabā'̄ìn, célebre gramático que aludió a la ceguera de Ma'arrī delante de un auditorio de sus admiradores, por lo que el poeta sirio desistió de acudir a sus reuniones. ḤUSAYN, Tāāā, Con $A b \bar{u}-l-$ 'Alā' en su prisión, p. 70.

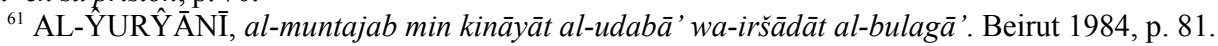

${ }^{62}$ Sarī', ì. En T. HUSAYN, Taŷdìd dikr Abì-l-'Alā', p. 173.

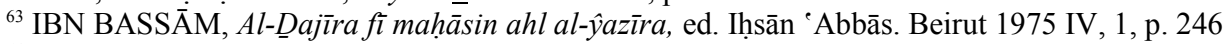

${ }^{64}$ Mutaqārib, lan. Ibid, IV, p. 247. 


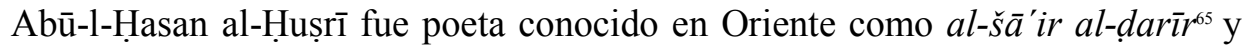
apreciado en el Magreb por al-Maqqarī ${ }^{\overline{6}}$. Era sobrino de Abū Isḥāq al-Husrī, autor del Zahr al-ādāb y, como él, estaba al servicio de los ‘Abbādíes de Sevilla, pero fue poco apreciado en lo personal y en lo literario en al-Andalus, por eso resulta sorprendente que el mismo Ibn Bassām que le reprocha su actitud interesada para con al-Mu tamid $^{67}$ en sus últimos días, le dedique en la Dajīra ni más ni menos que 38 páginas $^{68}$ en las que recoge también textos en prosa.

Mientras que $\mathrm{Ma}^{\circ}$ arrī consideraba ciego tanto al vidente como al invidente por su convicción de que el hombre, el mundo y el universo son inaprensibles, desconocidos y extraños a la razón, Al-Ḥușrī se enorgullece, al igual que Baššārar, de su ceguera física, que ambos ven como clarividencia.

En cierta ocasión respondió a un amigo que le había enviado un libro: "Pedí a mis amigos que me lo leyeran; cuando lo hicieron les encantó tu caligrafía, mientras que a mí me encantaron tu estilo y precisión. Ellos se deleitaron con los ojos, pero me deleitaron a mí con el oído y las ideas. Yo salí ganado y resulté más agraciado, pues vi toda clase de conocimientos que ellos no vieron". Ibn Bassām, fuente de la noticia, añade un comentario malicioso y fuera de lugar: "Estas palabras están ya muy trilladas y son copiadas; tal parece que hayan salido de este verso de al-Raḍ̂ $\vec{\imath}^{\prime}{ }^{69}$ :

No pude ver con mis ojos las moradas, quizás las vea con el oído. ${ }^{70}$

Ante la adversidad, al-Hușrī reacciona con cierta soberbia afrontando con orgullo una ceguera física que tiene a gala. Ma arrī, por el contrario, se encierra en la duda y la introspección, retirándose del mundo.

Dicen: te has quedado ciego. Respondo: qué va, ahora veo más que quien de verdad ve.

La negra niña del ojo ha visitado a un negro corazón

para desentrañar, los dos juntos, las cosas. ${ }^{71}$

Pero también sintió su discapacidad como una merma que ilustra con estos versos de Ŷarîr: "Si no tuviera las plumas cortadas volaría, pero ¿cómo volar si tengo las alas cortadas?" tras la pérdida de su hijo:

Soy un hombre sin amigos, hijos ni hermanos.

Al igual que la paloma lamento haber perdido la prole y ya no poder criar. $^{73}$

${ }^{65}$ IBN JALLIKĀN, III, 331-334.

${ }^{66}$ AL-MAQQARĪ, Nafh al-țīb. Ed. Iḥsān 'Abbās. Beirut 1968 IV, p. 109.

${ }^{67}$ Dajīra IV, 27.

${ }^{68}$ Dajīra, IV, I, pp. 245 a 283.

${ }^{69}$ Se trata del neoclásico Al-Šarīf al-Raḍī (m. 1016)

${ }^{70}$ Jafíf, 'ì. Dajīra IV, 248.

${ }^{71}$ Wãfir, ri, en Hasan Husnī 'ABD AL-WAHHĀB, Ta'rīj al-adab al-tūnisī min faŷr al-fath al'arabì li-Ifriqīya ilà al-aṣr al-hāọir. Túnez 1968, p. 162.

${ }^{72}$ Wäfir, hii, Dajīra IV , 1, p. 248.

${ }^{73}$ Maŷzū' al-jafíf, ji. Dajīra. IV, 1, p. 275. 
Gran aficionado a los versos amorosos dedicados a los gilmān, también él se enamora -tal es el peso del legado clásico- a través de los ojos invidentes:

En tu mejilla leo un mensaje de amor: la sangre derramada de los enamorados.

El sable de tus ojos, por su languidez, parece envainado y desenvainado a la vez. ${ }^{74}$

\section{AL-A'MÀ AL-TUTî̄LĪ (M. 1126)}

El ciego de Tudela fue apodado "El Ma'arrī de al-Andalus"'s. Harāma señala que no recibió este laqab solo por el mero hecho de ser ciego sino porque en sus trenos -lo mejor de sus poesía- se observa la influencia del gran poeta oriental en la actitud pesimista ante la vida y en la desolación, perplejidad e inquietud que se apoderan de él ante el gran enigma de la muerte ${ }^{76}$. Al-Ṣafadī le da el laqab de $a l$ darìr, mientras en su tierra se le dio el de $a l-a^{c} m a^{\eta 7}$, aunque también era conocido con el diminutivo al-ucayma, probablemente porque contrajo la ceguera de niño ${ }^{78}$. Autor de muwaššah y también de casidas clásicas, aceptó su invidencia con una resignación y tristeza contenidas, quizás porque la vivió antes como discriminación que como discapacidad: "Me siento apesadumbrado pero no avergonzado. Sobrellevo la discapacidad pero no soporto el menosprecio" "

Tengo unos ojos que, en lugar de miradas, vierten copioso llanto y exiguo sueño.

No puedo romper en sollozos pues las desgracias los han dejado secos. ${ }^{80}$

Lo más extraño en el amor es que alguien te quiera sin haberte visto. ${ }^{81}$

Al-Šaqundī pregunta: "¿Acaso tenéis a un ciego que dijo lo que dijo acerca de la pérdida de la vista y de sus cabellos negros?"

Sin duda el paso de los días ha hecho mella en mí hasta dejarme reducido a lo que veis.

No contento con haber dado buena cuenta del negro de mis ojos

vuelve ahora a acabar con el poco cabello negro que me queda. ${ }^{83}$

También él brilla al describir escenas inimaginables para un ciego: el despliegue de una flota en el mar o la caza de la liebre, tal como comenta Nuin ${ }^{84}$. En estos versos de elogio llega a hacer alusiones a una vista que no posee:

${ }^{74}$ Munsarih, lu. Dajīra IV, p. 256.

${ }^{75}$ IBN SA'ID. El libro de las banderas de los campeones, ed. y trd. E. García Gómez. Barcelona 1978. (CXVI), p. 259.

76 'Abd Allāh AL-HARĀMA, al-a'mà al-tuțīlī, hayātu-hu wa-adabu-hu, Trípoli 1983, pp.217-219.

${ }^{77}$ Dajīra II, 2, 728-773. Véase también Al-a'mà al-tuțīlì, hayātu-hu wa-adabu-hu.

${ }^{78}$ AL-ṢAFADĪ, al-wāfì bi-l-wafayāt, ed. Ramaḍãn 'ABD AL-TAWWĀB. Beirut 1979, VII, Biog. 3062, pp. 126-132. También en Nakt al-himyān fi-nukat al-'umyān. El Cairo 1911, p. 110.

${ }^{79}$ Dajīra II, 2, p. 729.

${ }^{80}$ Tawūl, ri. Dīwān al-a'mà al-tutīilī, ed Insān 'Abbās, Beirut 1963, p. 72.

${ }^{81}$ Las moaxajas de El ciego de Tudela, trd. Milagros Nuin y Waleed Saleh. Pamplona 2001, p. 79 (n ${ }^{\circ}$ XIX).

${ }^{82}$ AL-ŠAQUNDĪ, Risāla fí faḍl al-andalus, ed. y trd. Emilio García Gómez. Madrid 1934, p. 84.

${ }^{83}$ Basìt, rì. Hemos tomado la variante que da al-Maqqarī, Nafh III, p. 207. 
Tu rostro está en mis ojos, tu existencia en mis manos, tu amor en mi corazón y tu recuerdo en mi boca ${ }^{85}$

Lo que, al parecer, sí poseía era la agudeza propia de los ciegos pues, según Ibn Jāqān ${ }^{86}$ : "Tenía una mente que ponía al descubierto lo oscuro que se oculta y sabía interpretar lo recóndito, aunque hubiese sido borrado, a la par que desvelaba con su boca los secretos conceptuales". Una mente que, a juicio del poeta, es el mejor órgano sensorial:

Mira con tu entendimiento pues los ojos mienten.

Escucha con los sentidos pues el oído traiciona

$\mathrm{y}$ no digas que todo aquel que tiene ojos tiene vista

pues el pastor ve lo que no ve todo un rebaño.

Cuánta pupila, al mirar algo que le interesaba, cae en el error

sufriendo alucinaciones en el duermevela

y cuántas veces sueña el hombre estando despierto ${ }^{87}$

Esta tristeza resignada contrasta con la amargura de Bašsār ibn Burd quien, en realidad, se rebela contra su discapacidad arrojándose al mundo de los placeres y la sensualidad. Pero por encima de las distintas maneras con que perciben su propia ceguera y, exceptuando a $\mathrm{Ma}^{\circ}$ arrī, para quien la humanidad entera es ciega, estos poetas comparten la creencia en la mayor agudeza del ciego con respecto al vidente:

La gente es toda igual hasta que la pones a prueba.

La inteligencia tiene el juicio que no posee la vista,

al igual que la espesura del bosque cuya vegetación se asemeja,

pero se diferencia por los frutos ${ }^{88}$

Bien distinto es el caso de aquellos que perdieron la vista por la fuerza; es el caso del andalusí Abū-l-Majšĩ (m. 796-822), a quien arrancaron los ojos y la lengua por haber participado en una conjura política. La ceguera, en este caso, se convierte en un drama de difícil superación:

Cuando la ceguera sobreviene a un hombre que antes vio queda, aunque vivo, como un muerto sepultado ${ }^{89}$

\section{LA CEGUERA COMO MOTIVO LITERARIO EN LOS AUTORES VIDENTES}

La discapacidad, el defecto, la dolencia y la enfermedad constituyen un motivo literario de larga tradición en la literatura árabe que se ocupa de ello, tanto en su vertiente mental (despistados, estúpidos, locos, chiflados), como en la social o moral (gorrones, gafes, avaros) y la física (ciegos, tuertos, bizcos, cojos, mancos, patizambos,

${ }^{84}$ Las moaxajas de El ciego de Tudela, 15.

${ }^{85}$ Kämil, mi. Dìwān, 171.

${ }^{86}$ IBN JĀQĀ̄N, Qalā'id al-'iqyān fi- mahāsin al-a yāān. Ed. Muhammad al-'Annābī. Túnez 1966, p. 315.

${ }^{87}$ Basìt, ânī. Dìwān, p. 218.

${ }^{88}$ Basìt, ri, Nafh IV, p. 321.

${ }^{89}$ AL-MALKI, Saeed Master, "Una lectura semántica de la casida de la ceguera de Abū-1-Majšī-1andalusî”, Anaquel de Estudios Árabes 22 (2011), p. 149. 
tartamudos e, incluso, leprosos y sarnosos). Son textos, generalmente de adab, que proporcionan anécdotas, jocosas o insólitas. Hoy pueden parecernos incorrectos y desconsiderados pero, lo cierto es que ponen de manifiesto la normalidad con que vivían, se movían y trabajaban estas personas, bien aceptadas, sobre todo respetadas, e integradas en la sociedad arabo-islámica, y cómo ciertos personajes, pese a adolecer de tales defectos, alcanzaron puestos relevantes en la sociedad o fueron destacados literatos.

Entre los prosistas que abordaron esta temática encontramos a al-Haytam Ibn 'Adī (m. 822) en su Kitāb al- burșān wa-l- urŷān (Libro de los leprosos y los cojos) y a al-Ŷāhị, quien trató la avaricia en su Kitāb al-bujalā' y nos habló de leprosos, cojos, ciegos y bizcos en Al-burșān wa-l-urŷān wa-l-'umyān wa-l-hawlān $n^{90}$, aunque lo cierto es que, respecto al tema que nos ocupa, tan sólo recoge una breve relación de ciegos y tuertos ilustres elaborada por Al-Haytam. Por su parte, Ibn al-Ŷawzī al-Qurašì al-Bagdādī (m. 1200) se ocupó de tontos y despistados en su Ajbār al-hamqà wa-l-mugaffilīn ${ }^{91} \mathrm{e}$ Ibn Habīb al-Nīsābūrī (m. 1009) de locos juiciosos en 'Uqalā' al-maŷānīn ${ }^{92}$.

En poesía sobresalió Ibn al Rūmī (m. 896), quien adquirió fama de describir con sumo acierto los defectos físicos, y en tal cometido se le consideraba especialista ${ }^{93}$. Pero la forma en que los poetas abordan la ceguera es bien distinta a cómo la abordaron los prosistas. Domina en aquellos el contenido reflexivo, espiritual y afectivo sobre el jocoso o meramente anecdótico y descriptivo, lo que evidencia el carácter y sabor poético de esta discapacidad que, en general, es vista como un acicate a la creación intelectual y un fortalecimiento de las facultades mentales y espirituales que, unido al conocido desarrollo de los sentidos que experimenta el invidente, hacen del poeta ciego un superdotado sensitivo, tanto en lo físico como en lo espiritual.

Aunque en al-Andalus al-Majzūmī de Almodóvar (s. XII), poeta ciego deslengüado y libertino, provocara con sus mordaces versos soeces réplicas ${ }^{94}$, lo cierto es que los ciegos, lejos de suscitar mofa y burlas, fueron en esta tierra más amenudo motivo de inspiración amorosa para algunos poetas videntes, como Ibn Jātima de Almería (m. 1369), quien les dedicó varias piezas entre las que destacamos ésta:

Excusadme de mi amor por los ojos enfermos, pues la gente no tiene poder para defenderse de ellos.

Esos ojos enfermos de oftalmía y de coquetería contagiaron mi corazón de dos enfermedades. No es extraño que me atacasen cuando eran espadas desnudas, pero ¿cómo atacan ahora que están envainadas?95

${ }^{90}$ Ed. Mūrsī al-Jūlī. Beirut 1981.

${ }^{91} 1^{\mathrm{a}}$ ed. Beirut 1985. Dār al-kutub al-'ilmiyya.

${ }^{92} 1^{\text {a }}$ ed. Beirut 1995. Dār al-kutub al-ilmiyya.

${ }^{93}$ Véase el poema $\mathrm{n}^{\mathrm{o}} 122$ sobre la tacañería en VEGLISON, J., La poesía árabe clásica, $\mathrm{n}^{\mathrm{o}} 122$, 170, y el ño 821 sobre un cojo, en Dīwān Ibn al-Rūmī, ed. Huusayn Nașșār. El Cairo 1977, v. III, 1071.

${ }^{94}$ Véase su confrontación con la poetisa Nazhūn al-Qalā'̄i en GARULO, Teresa, Dīwān de las poetisas de al-Andalus. Madrid, Hiperión 1986, pp. 110-118.

${ }^{95}$ Wãfir, ayni. El Dīwān de Ibn Jātima de Almería, trd. Soledad Gibert. Barcelona 1975, p. 132. Véanse también los fragmentos $n^{\circ} 47$ y 49. 
Quizás obedecieran estos versos a una moda porque otro autor del siglo XIV, el prestigioso gramático Abū Hayyān al-Garnāṭ̣̂ ${ }^{96}$ (m. 1344), cuya poesía ha sido estudiada por Celia del Moral ${ }^{97}$, también muestra complacencia e inclinación amorosa por estos ciegos que suscitan en él amor o ternura:

No ha dañado la belleza de aquel a quien amo el que las lanzas de sus ojos sin mella se hayan velado.

Fueron un día dos flores en un jardín que no han perdido su encantadora belleza cual espada que, ya sin su pulimento, sigue hiriendo y causando dolor al corazón que ha alcanzado. ${ }^{98}$

Cuántos ciegos tienen un rostro cual jardín lleno de tropiezos para el paseante, siendo sus mejillas rosas que sobrepasarían al narciso de sus ojos, si los abriera. ${ }^{99}$

Oh belleza de un ciego cuyo enamorado no temía el filo de su mirada y se embriagó de ella sin remedio. ${ }^{100}$

Por su parte, Ibn al-Jațî (m. 1374) queda prendado de un bizco. Mientras los textos en prosa acerca de este defecto subrayan su aspecto cómico, en poesía, por el contrario, sacan a la luz su vertiente sentimental y tierna:

¡Oh bizco, atraviesas el corazón con la flechas de tus párpados.

Por culpa tuya los sanos corazones se muestran enfermos.

Cuando la belleza vio que tu mirada poseía un excelente filo, la ha puesto oblicua a fin de que sea más cortante. ${ }^{101}$

La reflexión e imágenes sobre la ceguera que tanto ocuparon a poetas ciegos como videntes del período clásico, pierde fuerza y presencia en la poesía moderna, sin duda porque la presencia de esta minusvalía es menor en nuestros días; sin embargo su utilización simbólica no es infrecuente y bien merecería un estudio aparte. Presentamos como muestra de ello estos cuatro ejemplos de autores pertenecientes a distintas tendencias: mahŷarí, verso libre y poesía sin trabas.

El libanés Rašīd Ayyūb (m. 1941) ${ }^{102}$ queda prendado aquí de la alegría del ciego, sentimiento de conformidad y superación que suscita su admiración y contrasta con el sentimiento de tristeza que emana del ciego medieval:

Le he visto caminar, y su cayado llama a la puerta de la limosna.

${ }^{96}$ Biog. En Nakt al-himyān, p. 213 y en AL-MAQQARĪ, Nafh II, 535-584, biog. 216.

${ }^{97}$ DEL MORAL, Celia, "La poesía de Abū Hayyān al-Garnaṭ̂” Homenaje al profesor José María Fórneas Besteiro. Universidad de Granada 1995, I, 243-259 y, sobre todo, "De nuevo sobre la poesía de Abū Ḥayyān al-Garnaṭ̂i: el tema erótico" Miscelánea de Estudios Árabes y Hebraicos 47 (1998), 289-302.

${ }^{98}$ Basīt, bā- Naf̣ II, p. 547.

${ }^{99}$ Sarī', ni, Nafh II, p. 548.

${ }^{100}$ Tawìl, hāa, Nafh II, p. 548.

${ }^{101}$ Ṭaw̄l, dà. IBN AL-JAṬĪB, Libro de la magia y de la poesía, ed. y trd. José María Continente Ferrer. Madrid 1981, n 574, p. 147 y texto árabe, p. 48.

102 "El ciego", trd. de Leonor Martínez, Antología de la poesía árabe contemporánea. Madrid 1972, p. 83. 
Entre los caminantes anda pacientemente y en su rostro

brilla una expresión de alegría y de firmeza.

Y dije: -Alma, detente y mira: un ciego nos muestra qué dulce es la vida.

Para Badr Šākir al-Sayyāb (m. 1964), por el contrario, la ceguera es símbolo de derrota. En su poema "La ramera ciega" ${ }^{103}$, ésta se presenta como el alter ego de un mundo árabe decrépito:

Es una ciega. Sus pupilas apagaron el deseo de la sangre en los hombres...

La ceguera que envuelve sus ojos casi la desvela.

Al-Bayātī (m. 1999) va más allá y devuelve la vista a Ma arrī:

El viejo ciego de Ma arra abre desolado el ventanuco

$Y$ clava desdeñosamente la vista en el cielo. ${ }^{104}$

Al igual que hace Adonis (n. 1930), quien le restituye el arte de la lectura -que tanto echaba de menos Ma arrī- aplicado a una naturaleza y a una humanidad a las que nunca vio, pero a las que abrió nuevas vías de percepción con su respeto, comprensión y cercanía afectiva:

En el pasado eras ciego pero ahora eres futuro.

Lees los caminos y el espacio.

Los árboles, los campos y a la gente. ${ }^{105}$

\section{A MODO DE CONCLUSIÓN}

Hemos seleccionado aquellos versos en que destacados poetas árabes ciegos de la literatura árabe clásica nos hablan de la ceguera: al-A šà Maymūn ibn Qays (m. 629), Baššār ibn Burd (m. 784), Abū-l-'Alā’ al-Ma arrī (m. 1057), Abū-1-Hasan alHuuṣrī al-Qayrawānī (m. 1095) y al-A mà al-Tuțịlī (m. 1126). De su lectura se desprende que, pese a que cada uno de ellos adoptó una actitud distinta frente a su discapacidad, casi todos coincidieron en considerarse dueños de una mayor clarividencia y en el brillante empleo de insólitas imágenes visuales. Señalamos, también, el caso de algunos poetas granadinos del siglo XIV para quienes los invidentes fueron motivo de inspiración amorosa, quizá como fruto de una moda literaria pasajera, y la pervivencia de la ceguera como motivo de inspiración en la poesía árabe contemporánea.

103 "La ramera ciega" en AL-SAYYĀB, Badr Šākir, El canto de la lluvia, trd. Carolina Fraile. Madrid 1996, p. 145.

104 "Poema cinegético" en AL-BAYĀTĪ, ‘Abd al-Wahhāb, El que viene y no viene, trd. Federico Arbós. Madrid 1982, p. 27.

105 “Homenaje a Ma arrı̄” en ADONIS, Homenajes, trd. Maria Luisa Prieto. Madrid 1995, p. 99. 